\title{
FOREIGN LANGUAGE LEARNING AND EDUCATION IN MINORITY CIRCUMSTANCES. PROBLEMS AND POSSIBLE SOLUTIONS
}

\author{
Szilvia Batyi \\ University of Pannonia
}

\begin{abstract}
Some form of bi- and multilingualism means the natural lingual condition for more than the half of the population of the Earth. It is a substantial linguistic aim of the Transcarpathian Hungarian community that beside preservation of their mother tongue (the Hungarian), acquire the state language (the Ukrainian language) and the basis of at least one world language. But this aim is hindered by a lot of things in Transcarpathia. The goal of the study is to shed light on these problems and to find possible solutions based on two researches. The first research, which was carried out in the Tanscarpathian Hungarian schools, was to reveal the conditions and problems of foreign language education. The research threw light on numerous problems that approve the low level of foreign language knowledge of the Tanscarpathian Hungarian youth. Attitudes and stereotypes influence the success of foreign language acquisition. For this reason in the second part of the study I would like to show, what kind of stereotypes and attitudes can be discovered in the parents (who are lay linguistically and language pedagogically) concerning foreign languages, and within this especially concerning the English language. It appears from the interviews, that nor the attitudes of the state towards foreign languages that was inherited from the soviet system, neither the impassiveness of the parents improves the positive attitudes in the Transcarpathian Hungarian students towards foreign languages, and nor the state, neither the parents approve the motivation of foreign language acquisition.
\end{abstract}

Keywords: bilingual, foreign language, attitudes, stereotypes

\section{Introduction}

To study other languages and be able to communicate with native speakers of other languages is not a luxury, but a necessity (Emmanuel Alvarez-Sandoval 2005). Learning foreign languages 
in minority circumstances is very important from the point of view of emergence. Some form of bi- or multilingualism is natural lingual condition for more than the half the Earth's population (Göncz 2005). One of the most convincing reasons for it is Mackey's demonstration which contrasted the number of the world's languages with the number of existing states and appeared to show that the total number of languages spoken in the world is thirty or forty times the number of states (Mackey 1967). The very existence of the European Union promotes language diversity in its member states. Schools, the media, advertisements, and the free labour market all convey to parents, children and teachers just how important is to know foreign languages (especially English). It is a major linguistic aim of the Transcarpathian Hungarian community not only to preserve their mother tongue (Hungarian) but also to acquire the state language (Ukrainian) and a grounding in at least one world language. But in Transcarpathia there are many obstacles to this aim.

The aim of my presentation is to shed light on these problems and to identify possible solutions.

Most of the graduates of the Transcarpathian Hungarian schools leave school with low-level foreign language knowledge. The data derived from a sociolinguistic survey carried out in the Carpathian-basin (see Kontra 1996, Csernicskó 1998, Göncz 1999, Lanstyák 2000) show that the level of foreign language knowledge is the lowest in Transcarpathia in comparison with other Hungarian minorities in Carpathian-basin. It reveals that in general, Transcarpathians, in contrast to other minority communities do not speak a single western world language.

This study is based on two investigations conducted in the academic years 2006/2007 and 2007/2008. The researches are based on questionnaire and interview surveys. The first research, which was carried out in Tanscarpathian Hungarian schools, was to reveal the conditions and problems of foreign language education. The research threw light on numerous problems that result in the low level of foreign language knowledge of the Tanscarpathian Hungarian youth. The main problems are: the lack of appropriate textbooks, the lack of teaching aids, the lack of opportunities to practice language, the small number of lessons per week, heterogeneous classes with too many learners, etc. 


\section{First research}

As stated above, this research is based on questionnaires sent to schools and interviews with teachers. The questionnaire was delivered to all the Hungarian schools, to arrive an overall picture of the state of foreign language teaching in Transcarpathia. $67 \%$ of the questionnaires were completed and returned.

In Transcarpathian schools' three (western)-European languages are taught: English, German and French. A study of foreign languages taught in Transcarpathian Hungarian schools carried out by Orosz Ildikó in the academic year 1993/94 yielded the results below, shown alongside those obtained by the present research:

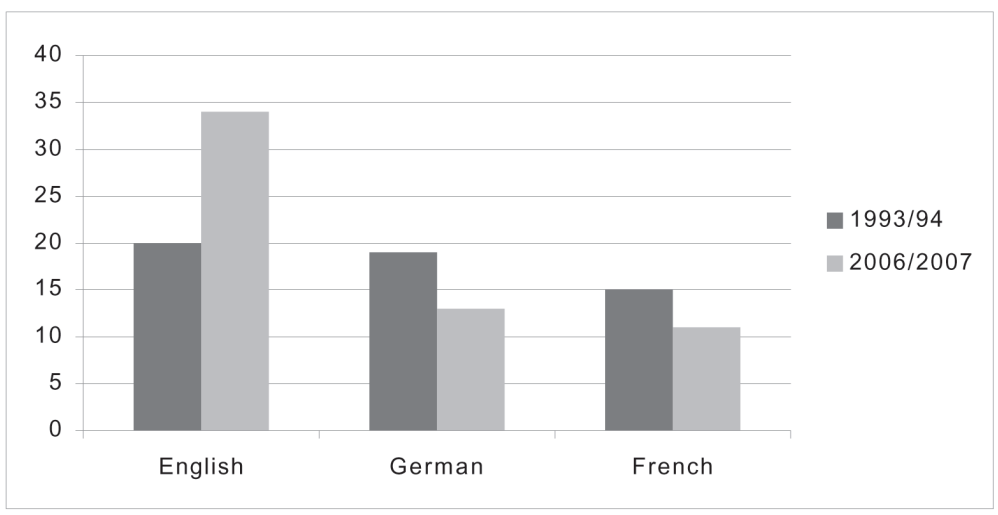

Figure 1. The distribution of foreign languages in schools in 1993/94 and in 2006/2007.

69 schools are compared is, because that was the number studied in the 1993/94 investigation The changes are significant! While, in the 1993/94 academic year, English was taught in 20 schools, in 2006/2007 it was being taught in 34 schools. However, there has been a decline in the teaching of German and French. More and more schools have introduced the teaching of English.

The schools studied fall into 4 types:

Elementary schools (forms 1-4)

Grade schools (forms 5-9) 
Secondary schools (forms 10-12)

Lyceums (forms 10-12)

The following diagram illustrates the trends according to school types.

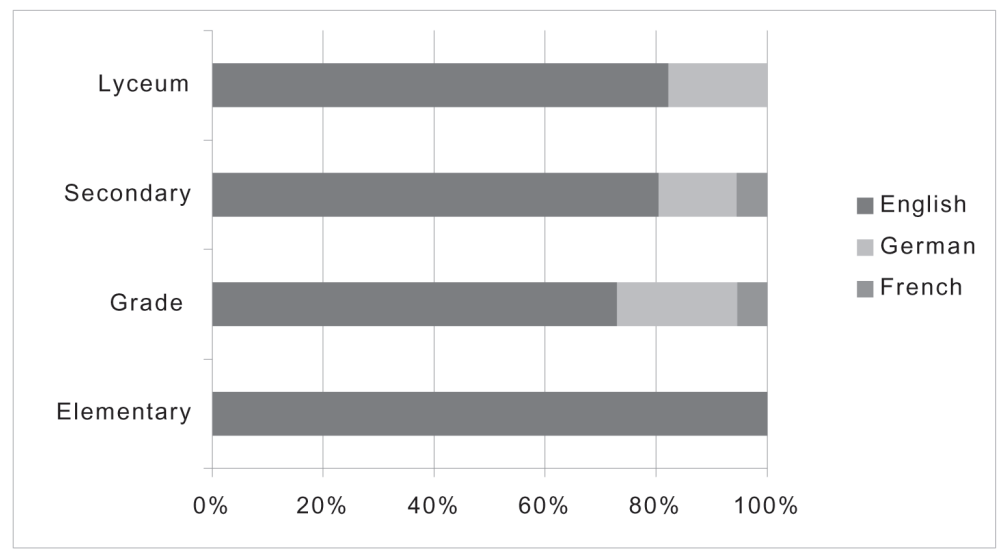

Figure 2. The distribution of foreign languages according to school types.

The positive tendency towards teaching and learning English is self-evident. In the elementary schools only English is taught and in lyceums only two languages, English and German are taught.

As the purpose of this study is to highlight the problems related to foreign language teaching in Transcarpathian Ukraine region and try to identify solutions, we should take into consideration all the components of foreign language teaching: curriculum, teachers, textbooks, teaching aids, number of lessons per week.

\section{Curriculum}

This is the fundamental framework of teaching. The curriculum ratified by the Ministry of Education of Ukraine is based on the Common European Framework of Reference for Languages. The focus is on the four language skills: reading, writing, speaking and listening. It is designed to develop these key aspects of communication in the chosen language and is, therefore, ideal. 


\section{Teachers}

The role of the teacher in foreign language teaching is vital.

The requirement by the Ministry of Education of Ukraine that foreign language teaching should be introduced in the second form highlighted a number of problems and, above all, the lack of appropriately skilled teachers. Most foreign language teachers in Transcarpathia are not trained to teach in the elementary classes. Obviously, there are significant differences between teaching a 7/9 year old child and a 16/17 years old youngster.

The Transcarpathian Hungarian College named after Rákóczi Ferenc II and the Human-Pedagogical College of Munkács identified the problem and tried to solve it in the way that they introduce English and German specialization in the teacher training faculty. Over time, this approach should help to overcome the problem.

What is the most important skill of a good language teacher? As mentioned above, interviews were carried out with different language teachers. Huszti Ilona, who teaches English methodology at the Transcarpathian Hungarian College named after Rákóczi Ferenc II responded that teachers should be very skilled and methodologically well-prepared.

Unfortunately, not all teacher-training colleges give equal emphasis to the importance of methodology.

A key forum for identifying and reviewing new methods in language teaching is the Summer Pedagogical Academy organised by the Transcarpathian Hungarian Pedagogical Association.

\section{The textbooks}

The textbook is a basic tool of foreign language teaching.

The problem is that foreign language textbooks are written for children whose mother tongue is Ukrainian, so the instructions in the book are in Ukrainian and the vocabulary in the book is also in Ukrainian. This is a serious problem, because a Hungarian pupil in the second form, who doesn't now either English or Ukrainian, can't use the textbook. Another problem is that the books are based on the grammar-translation method and doesn't contain enough situational or other tasks which prove the communication in the target language. 


\section{Number of lessons}

Teachers mentioned that the number of lessons per week is not enough. In Table 1 we can see how many lessons are in the different forms.

Table 1. Number of lessons per week.

\begin{tabular}{|l|l|}
\hline Form & $\begin{array}{l}\text { Number of lessons } \\
\text { per week }\end{array}$ \\
\hline 1st class* & - \\
\hline 2nd class & 2 \\
\hline 3rd class & 2 \\
\hline 4th class & 2 \\
\hline 5th class & 3 \\
\hline 6th class & 3 \\
\hline 7th class & 3 \\
\hline 8th class & 3 \\
\hline 9th class & 3 \\
\hline 10th class & 2 \\
\hline 11th class & 2 \\
\hline 12th class & 2 \\
\hline
\end{tabular}

*In the 1st form foreign language teaching is not compulsory.

So, in the lower classes the number of lessons per week is 2 , in the upper classes is 2 and 3.

\section{Second research}

In this part of the study which is based on an empirical research I would like to show what kind of stereotypes and attitudes can be discovered in the parents (who are lay linguistically and language pedagogically) concerning foreign languages, and within this especially concerning the English language (its "world language" status, its continuous spreading, its role in the labour market etc.), and concerning the teaching of the languages (the necessity of the teaching foreign languages, its circumstances, its methodological principles, the role of the teacher and the course book etc.). The survey was done among the parents of the pupils studying at the sixth form (11-12 years old). I chose four schools for my research: 
Table 2. The examined schools.

\begin{tabular}{|l|l|l|}
\hline School & Type & $\begin{array}{l}\text { Teaching } \\
\text { language }\end{array}$ \\
\hline $\begin{array}{l}\text { Secondary School of } \\
\text { Beregszász No 4 named } \\
\text { after Lajos Kossuth }\end{array}$ & City school & Hungarian \\
\hline $\begin{array}{l}\text { Hungarian Gymnasium } \\
\text { of Beregszász }\end{array}$ & City school & Hungarian \\
\hline $\begin{array}{l}\text { Secondary School of } \\
\text { Sislóc named after } \\
\text { Dobó István }\end{array}$ & $\begin{array}{l}\text { Village } \\
\text { school }\end{array}$ & $\begin{array}{l}\text { Hungarian, } \\
\text { Ukrainian }\end{array}$ \\
\hline $\begin{array}{l}\text { Secondary School of } \\
\text { Nagydobrony }\end{array}$ & $\begin{array}{l}\text { Village } \\
\text { school }\end{array}$ & Hungarian \\
\hline
\end{tabular}

I tried to choose the schools according to different aspects. The aspects were:

- type of school (secondary school or lyceum/gymnasium),

- teaching language of the school

- environmental language (if the pupil live and study in a school where the environment is bilingual it will not be unfamiliar for him to learn a foreign language).

The hypotheses were the following:

1. There is a connection between the effectiveness of foreign language learning and the parental stereotypes and attitudes.

2. The parents are not well-informed about the circumstances and conditions of the foreign language teaching in schools.

Nine parents were interviewed and ten parents filled in a questionnaire. The interview and the questionnaire contained similar questions to make clearer results.

\section{The most important language}

At the beginning of this study I emphasised how important nowadays to speak foreign languages, especially English. But for the question How do you think, what is the most important for- 
eign language? we got different answers. Some parents considered Ukrainian as the most important foreign language, and those parents who considered English as the most important foreign language they emphasised the importance of Ukrainian language through the whole interview. It is not strange or unusual that in Ukraine the Ukrainian language is a foreign language. As the foreign language teaching is not effective, there are also numerous problems in the Ukrainian language teaching in Hungarian schools. One of the most important problems is that the Ukrainian language as a subject means the same in the Hungarian and the Ukrainian schools, so it is supposed that the Hungarian child has some basic knowledge of Ukrainian language when he goes to the first form. But it is not true. The course books, curriculum are based on grammatical issues not on communication.

\section{The importance of foreign language knowledge}

Parents think that it is good if their children speaks a foreign language and they listed different reasons to support it, e.g. Who knows what the future brings, or As many language you speak so many persons you are. These reasons, we must tell, are not so convincing. The question comes out: Is it necessary today in Transcarpathia to speak foreign languages besides the mother tongue and the state language? Does a person have advantages by knowing a foreign language? Nearly all the parents answered that here in Transcarpathia knowing foreign languages is not so important. It can be useful if the person works for an international firm or continues his studies abroad. We must say again that the answers of the parents are not surprising. Nevertheless, the Ukrainian state more and more tries to orientate to the west, still foreign language knowledge is not important in the country, for which there are a lot of evidence. In the year of 2008 there was no opportunity to pass final exam of any foreign language. It means that if somebody wanted to enter a university to study on faculty of English language, he/she didn't have to pass English exam. What is more, in Ukraine you can get a diploma or scientific degree only with the knowledge of Ukrainian language. As in the higher education there is no need of foreign language knowledge, in most jobs foreign language knowledge is not required, it is understandable that for the parents it is not a basic thing that their children could speak a foreign language. 
This under motivation from the direction of the parents, the state and because of this from the pupils is conducive to the low level of foreign language knowledge in the region. The situation is the same with the Ukrainian nationality as well.

Table 3. The percentage of the speakers in Transcarpathia who speak other languages besides their mother tongue according to the census data in 2001 .

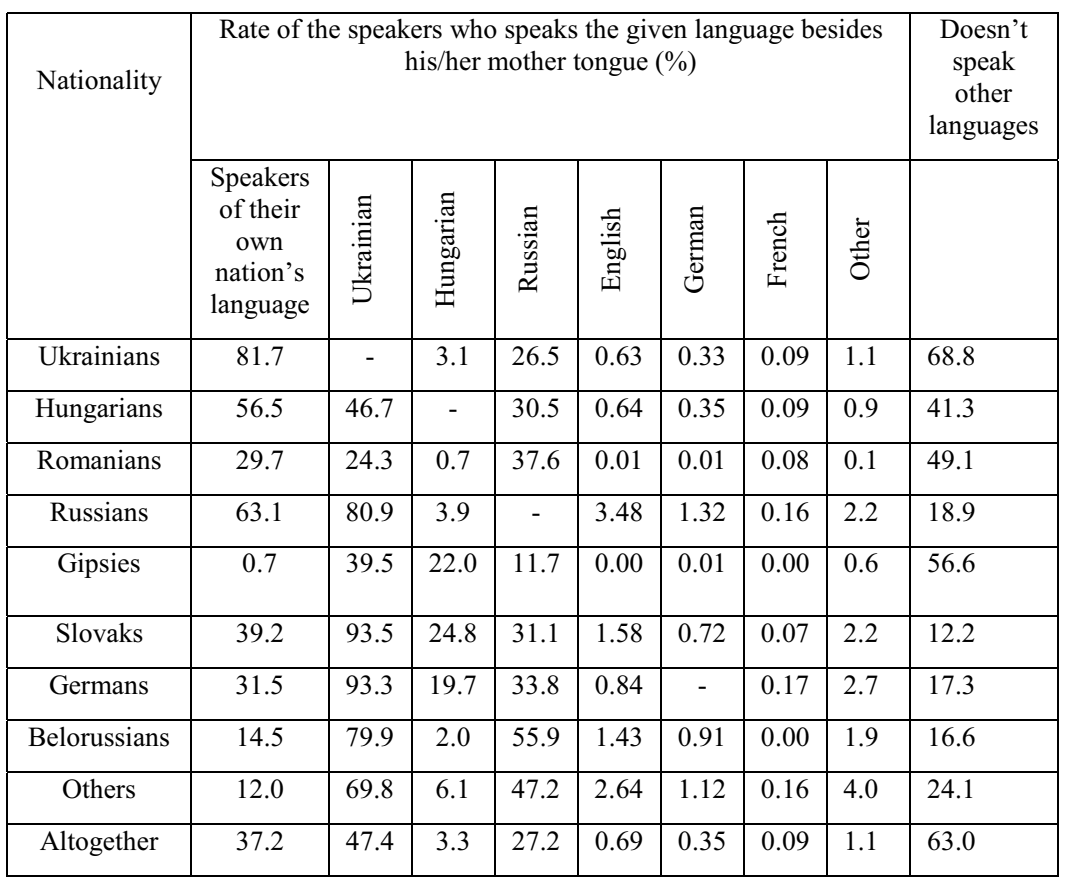

\section{The course book}

In most of the Transcarpathian Hungarian schools the foreign language books are used which were created for Ukrainian children. The main problem with them that they are based on a language which is genetically and typologically different from the Hungarian language and based on the grammatical-translation method, which is not the newest and most effective method in 
language teaching. There are books, which are based on modern methods but there is not enough in schools or only for classroom use. And the main problem that still remained: these books are not designed especially for Transcapathian Hungarian children.

\section{The teacher}

The teacher has a key role in foreign language teaching. We also asked parents about what kind of features should a good language teacher possess. The following answers came: He/she should be friendly, kind, strict, sympathetic, she can motivate children, and she can present the topic understandable. What is very interesting that the importance of professional knowledge is not in the line of the features.

\section{Summary}

As a summary we can say that in the Transcarpathian Hungarian schools needs a change in the area of approaches and methods concerning foreign language teaching. Such approaches and methods should be used that consider the distinctiveness of the Transcarpathian Hungarian community, the groups within the community and they should harmonize with the linguistic and sociological aims of the community. But as long as the local Hungarian schools are the units of the centralised Ukrainian state education structure, the Hungarian school network works according to the aims of the majority elite and not according to the aims of the Transcarpathian Hungarian community. One of the explanations can be this for the low efficiency of foreign language and state language education.

It appears from the research conducted among parents, that nor the attitudes of the state towards foreign languages that was inherited from the soviet system, neither the impassiveness of the parents improves the positive attitudes in the Transcarpathian Hungarian students towards foreign languages, and nor the state, neither the parents approve the motivation of foreign language acquisition. And it is well-known, that the attitudes, stereotypes and motivation have a determining role in language acquisition. 
Address:

Szilvia Batyi

Erdö hivatal str. 7

89463 Nagydobrony

Ukraine

E-mail: sissy@kmf.uz.ua

\section{References}

Alvarez-Sandoval, Emmanuel (2005) The importance of learning a foreign language in a changing society. USA: Iuniverse Inc.

Beregszászi, Anikó (2004) Idegennyelv-oktatásunk gondjairól és feladatairól szociolingvisztikai nézőpontból. [The problems and tasks of foreign language education from sociolinguistic perspective.] In: Huszti Ilona, szerk. Idegennyelv-oktatás kisebbségi környezetben, 10-20. Ungvár: Poliprint. Csernicskó, István (1998) A magyar nyelv Ukrajnában (Kárpátalján). [Hungarian language in Ukraine.] Budapest: Osiris Kiadó, MTA Kisebbségkutató Mühely.

Göncz, Lajos (1999) A magyar nyelv Jugszláviában (Vajdaságban). [Hungarian language in Yugoslavia.] Budapest and újvidék: Osiris Kiadó, Forum Könyvkiadó, MTA Kisebbségkutató Mühely.

Göncz, Lajos (2005) A kétnyelvűség pszichológiája. [The psychology of bilingualism.] In Lansták, István and Ildikó Vanèoné Kremmer, szerk. Nyelvészetról változatosan. Segédkönyv egyetemisták és a nyelvészet iránt érdeklödók számára, 33-76. Dunaszerdahely: Gramma Nyelvi Iroda.

Kontra, Miklós (1996) Magyar nyelvhasználat határainkon túl. [Hungarian language use outside Hungary.] In Diószegi, László, szerk. Magyarságkutatás 1995-1996, 113-123.. Budapest: Teleki László Alapîtvány.

Lanstyák, István (2000) A magyar nyelv Szlovákiában. [Hungarian language in Slovakia.] Budapest and Pozsony: Osiris Kiadó, Kalligram Kiadó, MTA Kisebbségkutató Mühely.

Mackey, William (1967) Bilingualism as a world problem/Le bilingüisme: phenomène mondial. Montreal: Harvest House.

Kokkuvõte. Szilvia Batyi: Võõrkeeleõpe ja haridus vähemustingimustes. Probleemid ja võimalikud lahendused. Enam kui poolele maakera rahvastikust on kaks- ja mitmekeelsus tavapärane olukord. TagaKarpaatia ungari kogukond omandab lisaks emakeelele (ungari keel) ka riigikeele (ukraina keel) ja vähemalt ühe maailmakeele alused. Taga- 


\section{Szilvia Batyi}

Karpaatias on palju asjaolusid, mis seda takistavad. Uurimuse eesmärk on heita valgust nendele probleemidele ja leida võimalikke lahendusi, tuginedes kahele teaduslikule uurimusele. Esimese uurimustöö, mis viidi läbi Taga-Karpaatia ungari koolis, eesmärk oli välja selgitada võõrkeele õpetamise tingimused ja tuua välja sellega seotud probleemid. Uurimustöö heitis valgust mitmetele probleemidele, mis näitasid TagaKarpaatias elavate noorte ungarlaste võõrkeeleoskuse madalat taset. Võõrkeele omandamise edukust mõjutavad hoiakud ja stereotüübid. Oma uurimuse teises osas soovin näidata, milliseid stereotüüpe ja hoiakuid võõrkeele õppimise osas oli võimalik leida vanemate seas, kes on keeleteaduslikult ja keelepedagoogiliselt asjatundmatud, eriti selles osas, mis puudutab inglise keelt. Intervjuudest selgus, et sotsialistliku süsteemi ajast pärinev riigitasandil võõrkeeltesse suhtumine ja ka vanemate ükskõiksus ei paranda Taga-Karpaatia ungarlastest tudengite positiivset suhtumist võõrkeeltesse, samuti ei motiveeri riik ega vanemad võõrkeelte omandamist.

Märksõnad: kakskeelne, võõrkeel, hoiakud, stereotüübid 